\title{
Мудрые наставления эвенкийской писательницы Галины Кэптукэ (Посвящается 65-летию Г.И. Кэптукэ)
}

\author{
Иванова Т., учащаяся, \\ ГБОУ РС (Я) «ЭШИ Арктика», \\ 2. Нерюнгри \\ Научный руководитель: \\ учитель КНРС (Я) Егорова М.В.
}

Главной особенностью обращения Г.И. Кэптукэ к эвенкийскому фольклору - это точное, прямое цитирование устнопоэтических текстов. У эвенков в целом фольклор имеет в значительной степени выраженное живое бытование. Эвенкийский фольклор функционирует не только в ритуально-обрядовой сфере, но и бытовой. Потому включение фольклорных образцов в литературный текст без каких-либо изменений сохраняет народное "'эпическое знание", но сохраняет его уже посредством нефольклорной формы. Г.И. Кэптукэ, выросшая в стихии фольклорной традиции, знаток специфики жанрового становления фольклора и его образно-стилевых особенностей, очень точно в своей повести (не исключаю, быть может, и не осознано) воспроизводит образцы эпического наследи своих сородичей. Включая обряд и сопровождающую его песню в художественное повествование, автор не привносит в их описание ничего своего. Это, на наш взгляд, определено целью закрепления его первичного облика и, быть может, последующим функциональным его возвращением в бытовую сферу жизни сородичей. Основанием такому заключению служит высказывание самой Кэптукэ о том, что "эвенкийский фольклор на современном этапе уже перестает быть единственной сферой, порождающей словесные тексты, которые составляют культурную традицию этноса. Таким образом, Г.И. Кэптукэ, как прозаик и ученый фольклорист сохраняет "эпическое знание" посредством нефольклорной формы. Письменная литература в творчестве Г.И. Кэптукэ обретает новое функциональное качество, - становится хранилищем традиционного фольклора, способом его консервации. Цитация фольклорных образцов у Г.И. Кэптукэ тоже своего рода способ хранения "эпического знания" в семантической памяти народа.

\section{Мудрые наставления Галины Кэптукэ}

1. «Но у меня тоже есть язык, он не хуже отцовского ножа, скажу, как отрежу»

- Не прибегайте, люди, к физической силе и оружию, когда можно доказать что-то словом. Сила слова еще никогда не измерялась силой голоса!

- Знать и не забывать. А сказано-то, как кратко и просто, но как хорошо- уздечкой летящие

- Сила слова еще никогда не измерялась силой голоса!

- Встречай гостей, скажи им заслуженные ими слова, ведь так далек и труден был их путь. Твое слово будет радостью для них - они вернулись домой. Зови их, приветствуй, тогда они будут знать, что здесь живет будущий охотник, а значит, не пустует земля их, есть на ней человечек. Благослови их добрым словом!

2. «Эвенк человек шагающий, всю землю обойдет»

- Голова должна думать, а ноги ходить.

- Да как же человек может жить, сидя на одном месте.

- Моя тропа ещё не закончилась, значит, я должен идти. 
- У каждого человека своя тропа, не потеряй ее, не заблудись.

- Спросите у старого эвенка, каков его возраст. Он не скажет: «Мне столько-то лет», он обязательно скажет: «Я прошагал столько-то лет».

3. «Жизнь жизни»

- Пульс смерти, как капли, стекающие в воду, он слышен.

- Каждый из нас думает лишь о своей конкретной жизни, нужно помнить о Жизни жизни.

- Но книги есть книги, нужно сверять их с жизнью.

- Ленивый бог не нужен, ленивых не кормит тайга. Ленивые жить не должны.

- Крепка ли твоя Нить жизни? Не оборвется ли от испуга и неожиданности?

- Сможешь ощутить свою Нить жизни - все в порядке с Пульсом души.

4. «Как это просто и естественно знать то, что знали твои родители»

- Храни корень человека, не давай ему загнить нехорошими делами и свершениями.

- Земля, как и человек, всякой бывает: и гористой, и ровной и полной воды местами совсем сухой, безводной. Велика земля наша, ее извилины все не пройти человеку.

- Но они никак не могут понять, что с самого начала РАЗУМ ВЛАДЕЛ МИРОМ.

- Жизнь сложная, дочка. Грамотному человеку легче, он законы знает и себя защитить может.

- Разве можно плакать тогда, когда еще нужно надеяться на лучшее? Плакать, заранее ожидая горя - грех

- «Подаренное судьбой цени, береги, потерявши, будешь плакать, да не вернешь», говорят старые люди.

- Если в доме паук появится, приживется - это хорошо, это к добру.

5. «Мое детство ...»

- Куда нам уезжать, если здесь родились, если здесь закрыта моя детская пуповина.

- Солнце уже не раз посчитало все волоски на твоих бровях и ресницах, а ты и глаз не раскроешь. Солнечный луч устал щекотать твой подбородок, а ты все спишь.

- На малу, на почетном месте у задней стены, на отцовской подушке сидел кто-то. А сидел там сделанный из сухой травы, из седых прошлогодних волос кочек человечек.

- У огня твоего свой язык-речь есть, надо понимать его, уметь слушать огонь надо, Сатик! Эвенки-то с малых язык огня знают, верить надо в огонь - тогда он свое слово откроет тебе.

- На земле все в мире и согласии жить должно, и старое с новым - тоже не должны ссориться.

- Если не научишь молодую собаку ходить на зверя полугодовалым щенком, время будет упущено навсегда, потом из нее вряд ли выйдет настоящий охотничий пес...

- «Ну-ка, поддай пинком свою лень, разбуди в себе старательность!» (Дедовская приговорка).

- И если бы нашлось хоть одно чуткое сердце, то оно могло бы услышать, как скулят мальчишечьи души по тайге и свободе.

- Надо же... выходит, я стану тупее, чем написано на роду? Ведь родившись в тайге, я и должен был расти в тайге, чтобы быть тем, кем должен был быть. Ну, а как же тогда со школой? Ведь всем ясно, что грамотный умнее неграмотного, а значит, и мозг грамотного должен быть больше. Наверное, это относится только к животным.

- Грамотный человек не пропадет, грамотный человек найдет правду. 


\title{
Список литературы:
}

1. Айзенштадт А.М., Шейкин Ю.М. Музыка эвенкийских сказаний / В кн. Эвенкийские героические сказания - Новосибирск: Наука. 1990. - 200.

2. Василевич Г.М. Эвенки /Историко-этнографические очерки XVIII - нач. XX вв. Л. - 1969. - 397.

3. Гачев Г. Повесть эвенкини // Литературная учеба. - 1989. - 5.

4. Кэптукэ Г. Имеющая свое имя Джелтула-река. - Якутск, 1989. - 115.

5. Кэптукэ Г. Эпические традиции в эвенкийском фольклоре. - Якутск: Северовед, 1996. - 134.

6.Кэптукэ Г. Мой папа - Санта Клаус. - Якутск: Бичик, 2010.

7. Кэптукэ Г. Писатели Якутии детям. - Якутск: Бичик, 2009.

8.Лебедева Ж.К. О жанрообразовании в архаическом эпосе народностей Крайнего Севера. / Фольклор народов Дальнего Востока и Сибири. - Горно-Алтайск, 1986. - 334.

9. Окорокова В. Литературы народов Севера Якутии. - Якутск: Издательство Якутского государственного университета, 2000. - 61.

10. Санги В. Мы не такие древние как греки // Литературная учеба. - 1989. - 5.

11. Хазанкович Ю.Г. Эвенкийская литература. - М.: Макс-Пресс. - 2002. - 110.

12. Гачев Г. Повесть эвенкини//Литературная учеба. 1989. № 4. С. $72-77$.

13. Михайлов А. Новый этап в развитии литератур//Полярная звезда. 1993. № 2. C. 159-164.

\section{Образ города в поэме В.Я. Брюсова «Конь блед»}

\author{
Колесова А.С., студентка, \\ Технический институт (филиал) \\ Северо-Восточного федерального университета, \\ 2. Нерюнгри \\ E-mail: ayuunawinner@gmail.com
}

\section{Научный руководитель: стариий преподаватель Игонина С.В.}

Мотивы, темы и образы города в поэзии Серебряного века занимают особое место.

Начало XX века - сложное время для России, эпоха больших перемен, серьезных катаклизмов. В этот период российской истории происходит переоценка ценностей, ломка всего старого, уже устоявшегося в жизни. Безусловно, противоречивые события в стране (и первая русская революция 1905-1907 годов, и Первая мировая война, и расцвет промышленного производства, и строительство и расширение городов) повлияли как в целом на развитие культуры, так, в частности, и на дальнейшее развитие литературы. Поэты покидают уединенные дубравы и попадают в город. Поэзия становится городской.

В начале XX века происходит расцвет модернизма в России, появляется множество новых течений. Так, в конце 90-х годов XIX века в русской литературе заявляет о себе новое литературное направление - символизм, мэтром и 